\title{
Peningkatan Kemampuan Berpikir Kreatif Matematis Siswa melalui Creative Problem Solving
}

\author{
Ikhsan Faturohman ${ }^{1}$ dan Ekasatya Aldila Afriansyah ${ }^{2 *}$ \\ Program Studi Pendidikan Matematika, Institut Pendidikan Indonesia \\ Jalan Pahlawan No.32 Sukagalih, Garut, Jawa Barat 43216, Indonesia \\ 1'Ikhsanfatur15@gmail.com; ${ }^{2}$ ekasatyafriansyah@institutpendidikan.ac.id
}

Artikel diterima: 11-05-2019, direvisi: 19-06-2019, diterbitkan: 31-01-2020

\begin{abstract}
Abstrak
Berbagai penelitian mengemukakan kemampuan berpikir kreatif matematis siswa masih rendah. Siswa hanya mencontoh apa yang dikerjakan guru, tanpa makna, sehingga dalam menyelesaikan soal, siswa menganggap cukup mengerjakan seperti apa yang dicontohkan. Tujuan dari penelitian ini untuk mendapatkan bukti empiris serta mengetahui bagaimana peningkatan kemampuan berpikir kreatif matematis siswa dengan penggunakan model pembelajaran Creative Problem Solving. Metode penelitian yang digunakan dalam penelitian ini adalah kuasi eksperimen dengan satu kelas sebagai kelas eksperimen. Instrumen yang digunakan dalam penelitian ini berupa soal tes uraian yang diberikan sebelum dan setelah diterapkannya model pembelajaran, dengan pokok bahasan materi fungsi. Populasi pada penelitian ini adalah seluruh siswa kelas X SMAN 25 Garut dengan sampel satu kelas yaitu, kelas X MIA 3 sebanyak 32 siswa, diambil secara purposive sampling. Hasil penelitian menunjukan bahwa secara statistik peningkatan kemampuan berpikir kreatif matematis kelas Creative Problem Solving bartaraf sedang, maka dapat disimpulkan bahwa terdapat peningkatan kemampuan berpikir kreatif matematis siswa yang menggunakan model Creative Problem Solving.

Kata Kunci: Creative Problem Solving, Berpikir Kreatif Matematis, kuasi eksperimen.
\end{abstract}

\section{Enhanced Ability of Student Mathematical Creative Thinking with Creative Problem Solving}

\begin{abstract}
Different studies propose that students' mathematical creative thinking abilities are still weak. Students only imitate what the teacher is doing, without meaning, so that in solving problems, students assume enough to do as what is explained. The objective of this study is to obtain empirical evidence and find out how to enhance students' mathematical creative thinking abilities by using the Creative Problem Solving learning model. The study method is a quasiexperiment with one class as an experimental class. The instrument was in the form of a test item given before and after the learning model was performed, with the subject theme functioning. The population in this study were all students of class X SMAN 25 Garut with a sample of one class that is, class X MIA 3 as many as 32 students, taken by purposive sampling. The outcomes of the study revealed that statistically increasing the ability to think mathematically in a creative class of moderate problem-solving problem, it can be assumed that there was an improvement in students' mathematical creative thinking ability using the model of creative problem-solving.

Keywords: Creative Problem Solving, Mathematical Creative Thinking, quasi-experiments.
\end{abstract}




\section{Pendahuluan}

Matematika sebagai media atau sarana dalam mendukung siswa mencapai suatu kompetensi yang diharapkan (Damayanti \& Afriansyah, 2018). Belajar materi matematika diharapkan siswa mampu mencapai suatu kompetensi yang telah ditetapkan. Hal itu merupakan gambaran karakteristik matematika sebagai suatu kegiatan manusia yang dikenal dengan sebutan mathematics as a human activity (Sumarmo, 2013; Afriansyah, 2016).

Salah satu kompetensi matematis yang diharapkan di sekolah ialah siswa mampu memiliki kemampuan berpikir matematis (Afriansyah, dkk., 2019). Kemampuan berpikir matematis yang sangat diperlukan siswa yang terangkum dalam kemampuan berpikir kritis, pemecahan masalah, koneksi matematis, penalaran matematis dan berpikir kreatif matematis perlu mendapat perhatian lebih pada proses pembelajaran (Fatwa, Septian, \& Inayah, 2019) di dalam kelas ataupun di luar kelas.

Kemampuan berpikir kreatif merupakan kemampuan yang dikategorikan sebagai kemampuan berpikir tingkat tinggi atau High Order Thinking (HOT). HOT menjadi salah satu tujuan dari kurikulum 2013 yang harus dicapai oleh siswa (Gais \& Afriansyah, 2017). Peraturan menteri no 22 tahun 2006 agar siswa, melalui pembelajaran sekolah dapat memiliki kemampuan berpikir kreatif (BNSP, 2006).
Hal tersebut menjelaskan bahwa pentingnya kemampuan berpikir kreatif dalam segala bidang tak terkecuali dalam bidang matematis. Kemampuan berpikir kreatif matematis merupakan kemampuan yang penting untuk dimiliki oleh seseorang (Pangestu \& Yunianta, 2019), akan tetapi nyatanya hasil belajar matematika siswa di sekolah belum menunjukan hasil yang menggembirakan, khususnya dalam aspek berpikir kreatif matematis (Teti, 2015).

Menurut Rusman (Huda, 2011), "Berpikir kreatif merupakan proses pembelajaran yang mengharuskan guru untuk dapat memotivasi dan memunculkan kreativitas siswa selama pembelajaran berlangsung, dengan menggunakan beberapa metode dan strategi yang bervariasi, misalnya kerja kelompok, bermain peran, dan pemecahan masalah". Dalam belajar matematika, siswa hendaknya memahami hubungan antara ide-ide matematis dan bidang studi lainnya (Afriansyah, 2015). Ketika siswa telah mampu mengkreativitaskan beberapa ide matematis, maka siswa dapat memperoleh pemahaman yang lebih baik.

Berdasarkan pernyataan tersebut, kemampuan berpikir kreatif matematis penting untuk dimiliki siswa dan perlu dilatihkan pada setiap siswa, jika siswa mampu mengaitkan ide-ide matematika maka kemampuan pemahaman 
matematisnya akan semakin baik dan lebih bertahan lama (Afriansyah, 2012), karena siswa mampu melihat kreativitas antar topik dalam matematika (Rahmi, 2015).

Rendahnya kemampuan berpikir kreatif matematis siswa pun sitemukan dalam penelitian Novi (2016). Hal ini disebabkan oleh proses pembelajaran matematika yang masih cenderung monoton (Afriansyah, 2013) dan terlalu memaksakan cara berpikir yang dimiliki gurunya. Akibat dari pembelajaran tersebut, siswa bersikap pasif, hanya mencontoh apa yang guru kerjakan, tanpa memahami maknanya. Wahyudin (Novi, 2016) menyatakan penyebab rendahnya kemampuan berpikir kreatif matematis siswa dalam pembelajaran matematika diantaranya karena proses pembelajaran yang belum optimal. Selain itu banyak guru yang kurang memperlihatkan penggunaan konteks yang bersumber dunia nyata, padahal konteks dapat membangkitkan pengetahuan dan keterampilan siswa melalui pengalaman nyata (Afriansyah, 2014). Sehingga siswa sulit mengaplikasikan pengetahuan mereka dalam matematika ke dalam kehidupan nyata.

Proses pembelajaran yang belum optimal inilah yang harus coba diperbaiki agar dapat mencapai tujuan yang diinginkan. Proses pembelajaran yang guru gunakan haruslah menjadi jalan terciptanya proses pembelajaran yang optimal (Luritawaty, 2019; Afriansyah, 2017) sehingga dicapailah tujuan pembelajaran tersebut. Berkenaan dengan proses pembelajaran yang baik, dibutuhkan model pembelajaran yang sesuai dalam meningkatkan kemampuan berpikir kreatif matematis siswa. Banyak model pembelajaran yang bisa diterapkan untuk pembelajaran matematika (Ridia \& Afriansyah, 2019) dengan tujuan tersebut, misalnya model pembelajaran Creative Problem Solving.

Menurut (Pepkin, 2004), Creative Problem Solving merupakan salah satu model yang melatih siswa untuk berpikir kreatif. Model ini memberikan kebebasan pada siswa untuk aktif dalam proses pemecahan masalah. Adapun sintak dalam model pembelajaran Creative Problem Solving diantaranya meliputi, klarifikasi masalah, mengungkapkan gagasan, evaluasi dan seleksi, serta implementasi. Sehingga diharapkan siswa dapat terlatih dalam menalar, mengkontruksi serta mampu berpikir kreatif dalam memecahkan masalah. Sebelumnya, model pembelajaran ini pun pernah diteliti oleh Tarlina \& Afriansyah (2016), mereka berhasil menerapkan model pembelajaran ini pada materi garis dan sudut. Dalam penelitian ini, peneliti tertarik ingin mencoba model Creative Problem Solving pada materi fungsi.

Berdasarkan kajian yang peneliti lakukan terhadap model pembelajaran di atas, peneliti berkeyakinan bahwa model pembelajaran Creative Problem Solving dimungkinkan dapat mempengaruhi secara positif kemampuan berpikir kreatif 
matematis. Dalam beberapa penelitian sebelumnya diketahui bahwa model tersebut tergolong berhasil dan mampu meningkatkan kemampuan berpikir kreatif matematis, untuk mengetahui apakah model tersebut baik terhadap materi lainnya, maka peneliti mencoba melakukan penelitian dengan model tersebut dalam materi fungsi.

Dalam mengembangkan kemampuan berpikir kreatif matematis siswa diperlukan kesalerasan kreatifitas dari unsur-unsur pendidikan metematika, terutama guru sebagai pengajar yang dituntut dapat menghidupkan dan menstimulus siswa dalam berpikir kreatif. guru disamping memberikan motivasi juga harus mampu memberikan ide dan gagasan yang relatif berbeda sehingga siswa mampu menemukan sesuatu yang baru disetiap proses pembelajarannya (Dewi \& Afriansyah, 2018).

Berdasarkan latar belakang yang telah dimunculkan, masalah penelitian ini dirumuskan dalam pertanyaan: Bagaimana peningkatan kemampuan berpikir kreatif matematis siswa dengan model pembelajaran Creative Problem Solving (CPS)? Sementara itu, tujuan dalam penelitian ini adalah untuk mengetahui terdapat atau tidak terdapatnya peningkatan yang signifikan dari kemampuan berpikir kreatif matematis siswa yang mendapatkan perlakuan model pembelajaran Creative Problem Solving.

\section{Metode}

Metode yang digunakan peneliti adalah metode kuasi eksperimen, yaitu metode yang digunakan untuk melihat suatu pengaruh model pembelajaran. Penelitian ini dilakukan di SMAN 25 Garut dengan Populasi Seluruh siswa kelas X. Sampel pada penelitian ini adalah kelas $X$ IPA 3 sebagai kelas eksperimen, diambil secara purposive sampling.

Adapun desain penelitian ini adalah sebagai berikut:

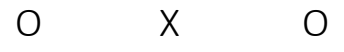

Keterangan:

$\mathrm{O}=$ Instrumen tes awal dan tes akhir

$X=$ Perlakuan dengan model pembelajaran Creative Problem Solving

--- = Pengambilan sampel idak dilakukan secara acak. 
Tabel 1.

Waktu Penelitian

\begin{tabular}{|c|c|c|c|}
\hline Waktu & Jam & Jenis Kegiatan & Materi/Topik \\
\hline Rabu, 23-01-2019 & $07.15-08.45$ & Pretest & - \\
\hline Jumat, 25-01-2019 & $07.15-08.45$ & Perlakuan ke-1 & Fungsi Linear \\
\hline Rabu, 30-01-2019 & $07.15-08.45$ & Perakuan ke-2 & $\begin{array}{c}\text { Menggambar grafik fungsi linear serta } \\
\text { menyelesaikan masalah kontetual yang } \\
\text { berhubungan dengan kehidupan sehari- } \\
\text { hari }\end{array}$ \\
\hline Jumat, 01-02-2019 & $07.15-08.45$ & Perlakuan ke-3 & Fungsi Kuadrat \\
\hline Rabu, 06-02-2019 & $07.15-08.45$ & Perlakuan ke-4 & $\begin{array}{c}\text { Menggambar garfik fungsi kuadrat serta } \\
\text { menyelesaikan masalah kontetual yang } \\
\text { berhubungan dengan kehidupan sehari- } \\
\text { hari }\end{array}$ \\
\hline Jumat, 08-02-2019 & $07.15-08.45$ & Postest & - \\
\hline
\end{tabular}

Instrumen yang digunakan dalam penelitian ini adalah tes kemampuan berpikir kreatif berupa tes tulis yang terdiri dari tes awal (pre-test) dan tes akhir (posttest). Bentuk dari tes merupakan tes uraian yang terdiri dari 4 butir soal kemampuan berpikir kreatif. Soal tersebut sebelumnya telah diujukan pada kelas dengan jenjang yang lebih tinggi yang mana kelas tersebut telah mempelajari materi fungsi dan relasi sebelumnya, setelah dilakukan uji coba, data tersebut diolah dengan mengukur validitas, reliabilitas, daya pembeda, serta tingkat kesukaran. Hal tersebut digunakan untuk menjadi tolak ukur kualitas butir soal yang akan diberikan.

Penelitian ini dilaksanakan kurang lebih selama tiga minggu dengan jumlah enam kali pertemuan pada tanggal 23 Januari sampai 8 Februari 2019, sedangkan penelitian dilaksanakan di SMA 25 Garut, di kelas X IPA 3 dengan waktu penelitian disesuaikan dengan jadwal yang ada (lihat tabel 1).

\section{Hasil dan Pembahasan}

\section{A. Hasil Penelitian}

Untuk menguji normalitas data pretest peneliti penggunakan uji Liliefors. Hasil dari uji normalitas data disajikan dalam tabel 2.

Berdasarkan data pada Tabel 2 diperoleh bahwa nilai $\mathrm{L}_{\text {maks }}=175$ kelas yang menggunakan model pembelajaran Creative Problem Solving sebelum

Tabel 2.

\begin{tabular}{cccc}
\multicolumn{4}{c}{ Hasil Uji Normalitas Data Pretest dan Posttest } \\
\hline Kelas & Lmaks & Ltabel & Kriteria \\
\hline $\begin{array}{l}\text { CPS sebelum } \\
\text { pembelajaran }\end{array}$ & 0.175 & 0.159 & $\begin{array}{c}\text { Tidak } \\
\text { Berdistribusi } \\
\text { Normal }\end{array}$ \\
\hline $\begin{array}{c}\text { CPS sesudah } \\
\text { pembelajaran }\end{array}$ & 0.131 & 0.159 & $\begin{array}{c}\text { Berdistribusi } \\
\text { Normal }\end{array}$ \\
\hline
\end{tabular}

Tabel 3.

Deskripsi Data Tes Akhir Menggunakan Gain Ternormalisasi

\begin{tabular}{cccc}
\hline Kelas & $\begin{array}{c}\text { Jumlah } \\
\text { siswa }\end{array}$ & Ratarata & $\begin{array}{c}\text { Simpangan } \\
\text { baku }\end{array}$ \\
\hline $\begin{array}{c}\text { Creative } \\
\text { Problem }\end{array}$ & 32 & 0,56 & 2,72 \\
Solving & & & \\
& & &
\end{tabular}


Tabel 4.

Presentasi Gain Ternormalisasi

\begin{tabular}{cccc|}
\hline No & Interpretasi Gain & fi & Persentase \\
\hline 1 & Rendah & 4 & 12.5 \\
\hline 2 & Sedang & 20 & 62.5 \\
\hline 3 & Tinggi & 8 & 25 \\
\hline & Jumlah & 32 & 100 \\
\hline
\end{tabular}

pembelajaran, dan $\mathrm{L}_{\text {tabel }}=0.159$. Jadi, $L_{\text {maks }}>$ Ltabel sehingga data posttest kelas dengan Creative Problem Solving tidak berdistribusi normal. Sedangkan data yang diperoleh sesudah model pembelajaran diterapkan, diperoleh $L_{\text {maks }}$ kelas dengan Creative Problem Solving adalah 0,131 dan Ltabel dengan derajat kebebasan 5\% adalah 0,159 yang menunjukan bahwa data tersebut berdistribusi normal.

Seberapa besar peningkatan kemampuan berpikir kreatif matematis pada kelas Creative Problem Solving dapat dilihat pada tabel 3. Pada tabel ini dapat diketahui bahwa nilai rata-rata indeks gain untuk kelas Creative Problem Solving adalah 0.56, maka nilai tersbut dapat dikatakan tergolong sedang secara statistik.

Peningkatan kelas Creative Problem Solving termasuk ke dalam ketegori sedang dengan jumlah 32 siswa 62.5\% termasuk kategori sedang, 25\% termasuk kategori tinggi dan 12\% termasuk kategori rendah (lihat tabel 4).

\section{B. Pembahasan}

Penelitian dilaksanakan kurang lebih selama tiga minggu dengan jumlah enam kali pertemuan yaitu pada tanggal 23 Januari 2019 sampai tanggal 8 Februari 2019, untuk populasi yang diambil adalah seluruh siswa kelas X SMA Negeri 25 Garut dengan sampel kelas yang telah ditentukan oleh guru sebelumnya yaitu kelas X IPA 3 dengan jumlah 32 siswa sebagai kelas eksperimen, kelas tersebut pertama diberikan pretest dengan tujuan melihat kemampuan awal kelas tersebut.

Dalam penelitian ini peneliti membuat perangkat pendidikan berupa RPP yang disesuaikan dengan jumlah pertemuan yang diberikan, disertakan LKS untuk menguji sejauh mana penerimaan pembelajaran yang didapat siswa, Dengan menggunakan LKS pada kelas Creative Problem Solving siswa diarahkan untuk dapat mencari solusi dari permasalahan secara kreatif,

Seperti yang telah dijelaskan bahwa pembelajaran menggunakan Creative Problem Solving ini dibantu dengan Lembar Kerja Siswa (LKS), lembar evaluasi dan Buku paket untuk memudahkan peneliti dalam menyampaikan materi sebagai media pembelajaran. Pada awal pelaksanaan proses pembelajaran di kelas yang mendapatkan model pembelajaran Creative Problem Solving, umumnya siswa masih tampak belum mengerti dan 
memahami proses pembelajaran. Siswa masih bingung dengan pembelajaran yang dilakukan secara berkelompok yang terdiri dari lima sampai enam orang perkelompok secara heterogen dan siswa harus mengerjakan LKS yang menuntun siswa dalam mencari berbagai macam cara dalam menyelesaikan permasalahan mengenai materi fungsi.

Pada saat mengerjakan LKS, siswa masih perlu dibimbing oleh peneliti sebab siswa belum terbiasa menggunakan LKS sebagai media pembelajaran. Namun, pada pertemuan kedua dan selanjutnya pembelajaran sudah bisa dikondisikan sesuai dengan perencanaan. Beberapa siswa kelas X IPA 3 SMA Negeri 25 Garut yang dijadikan sebagai kelas eksperimen dengan model pembelajaran Creative Problem Solving tidak terlalu antusias karena pembelajaran tidak seperti biasanya, namun kebanyakan siswa mengaku bahwa dengan menggunakan model pembelajaran Creative Problem Solving suasana kelas menjadi lebih hidup dan pembelajaran tidak membosankan sebab belajar dilakukan secara berkelompok.

Creative Problem Solving merupakan hal yang baru di sekolah tersebut dan bagi siswa yang ada di kelas X IPA 3. Namun demikian, siswa di kelas tersebut tidak kesulitan untuk menyesuaikan diri dalam pembelajaran sehingga pembelajaran berjalan lancar dan kondusif. Siswa mulai terbiasa dengan model pembelajaran yang digunakan meskipun masih ada beberapa siswa yang tidak dapat mengikuti alur pembelajaran dengan baik.

Pada kegiatan inti, siswa dibagi menjadi beberapa kelompok secara heterogen yang terdiri dari tiga sampai empat orang dalam satu kelompok. Siswa duduk berdasarkan urutan kelompoknya dan masing-masing kelompok diberikan LKS. Media pembelajaran berupa LKS tersebut dibuat agar siswa dapat menyelesaian permasalahan dengan harapan solusi yang diperoleh memiliki banyak cara mengenai materi fungsi. Hal ini diberikan sesuai dengan tahap klarifikasi masalah yang meliputi proses memahami masalah, dimana siswa mendalami permasalahan langsung yang diberikan dan diharapkan dengan tahap memahami masalah ini mampu menemukan fakta-fakta yang mendasari masalah tersebut. Permasalahan yang diberikan didiskusikan bersama dengan kelompoknya (lihat gambar 1).

Pada tahap klarifikasi masalah peran guru sangat penting yaitu sebagai fasilitator. Pada tahap ini, sesuai dengan apa yang

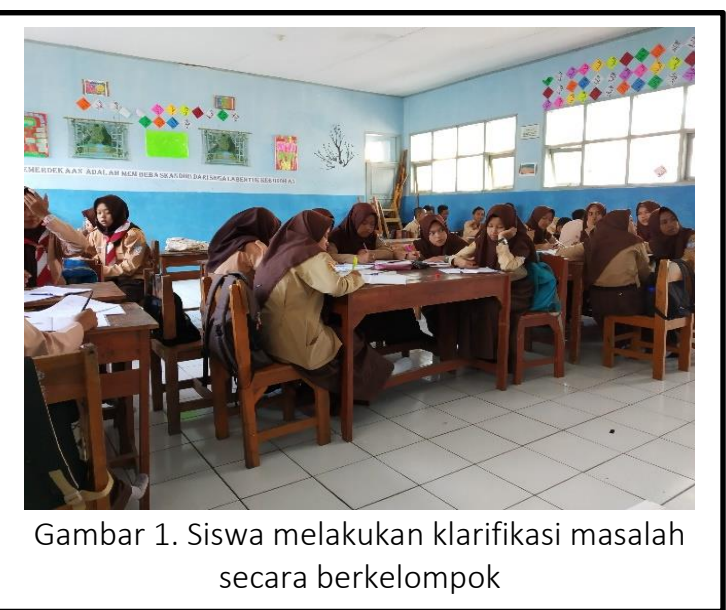


dikemukakan Maryanti (2012), guru perlu mengarahkan siswa menuju pengetahuan baru dan mencoba memberikan pemahaman mengenai suatu permasalahan yang mereka temukan. Permasalahan yang diberikan dibuat sedemikian rupa sehingga siswa mampu menemukan cara yang tak biasa dalam menyelesaikan permasalahan mengenai materi fungsi.

Pada saat mengisi LKS, masing-masing kelompok diperbolehkan untuk menungkapkan gagasan berbagai macam strategi penyelesain masalah, Ini merupakan tahap dimana siswa menemukan cara baru yang mereka temukan dari hasil diskusi kelompoknya mengenai permasalahan yang diberikan. Pada tahap ini, siswa memasuki tahap pengungkapan gagasan.

Pada tahap implementasi salah satu perwakilan kelompok mempersentasikan hasil temuannya di depan kelas. Pada tahap ini setiap kelompok melakukan interaksi secara langsung, dimana kelompok yang tidak memaparkan hasil diskusinya bisa menanggapi hasil diskusi kelompok lain. Banyak manfaat pada tahap ini salah satunya terlihat dari perbedaan cara mereka dalam menemukan solusi penyelesaian dari sebuah permasalahan, meskipun cara yang ditemukan mereka relatif sama.
Senada dengan pendapat Prayoga (2013), kegiatan persentasi yang dilakukan bertujuan agar siswa mampu mengungkapkan pendapat mereka terkait materi yang dipelajari. Adapun kegiatan presentasi yang telah dilakukan disajikan pada Gambar 2.

Pada tahap evaluasi yaitu tahap latihan dan dilanjutkan dengan penugasan, siswa diberikan soal-soal latihan untuk diselesaikan secara individu. Tahap ini bertujuan untuk mengukur tingkat kreatifitas siswa dalam proses pembelajaran yang sudah dilakukan sebelumnya (lihat gambar 3). Hal ini sesuai dengan pernyataan Setyanta (2013), Setyanta menegaskan bahwa pelaksanaan kuis bertujuan untuk menciptakan persaingan dan kompetisi di dalam kelas, menumbuhkan motivasi dan memberikan semangat siswa dalam belajar

Tahap-tahap tersebut berlangsung selama empat pertemuan, pada setiap pertemuan terlihat beberapa peningkatan baik dari motivasi mereka maupun

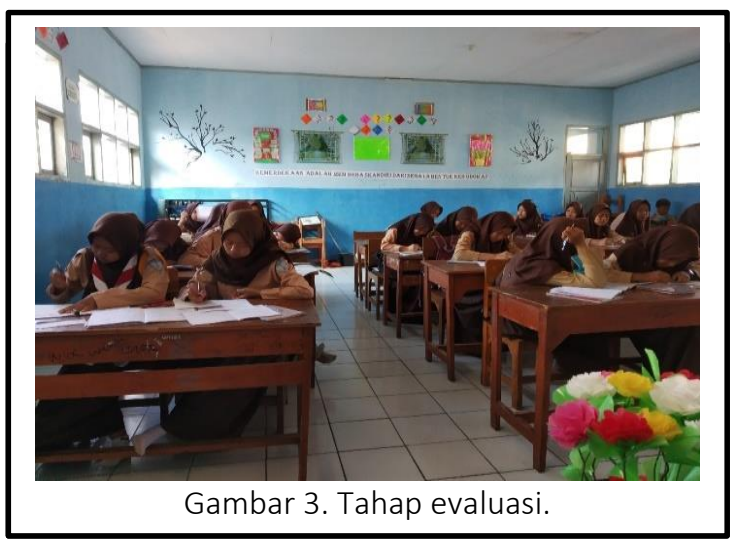


peningkatan pembelajaran. Tetapi pada pertemuan terakhir mereka terlihat mulai sedikit mengalami kejenuhan karena pembelajaran matematika dengan menggunakan media pembelajaran berupa LKS yang menuntun siswa untuk menemukan cara yang tak biasa adalah bukan perkara mudah. Oleh karena itu, peneliti memodifikasi LKS dengan memberikan ilustrasi yang menggambarkan situasi dari permasalahan yang diberikan.

Selanjutnya, peneliti akan membahas mengenai perkembangan siswa pada setiap pertemuan. Pertemuan pertama di kelas yang mendapatkan model pembelajaran Creative Problem Solving dibahas mengenai fungsi linear. Siswa diberikan permasalahan dilibatkan dalam kehidupan sehari-hari yang menggambarkan pola bilangan. Solusi permasalahan dari fungsi linear bisa siswa pahami sebab siswa menemukan sendiri dengan cara berdiskusi bersama kelompoknya masing-masing yang kemudian dipersentasikan untuk menyamakan solusi permasalahan tersebut. Pembelajaran berlangsung sesuai dengan langkah-langkah Creative Problem Solving, hanya saja pada pertemuan pertama ini saat tahap implementasi siswa masih terlihat malumalu dalam mengomentari hasil diskusi kelompok lain. Selain itu, siswa merasa terbebani pada tahap evaluasi yakni pemberian tugas individu berupa soal-soal latihan. Namun, hal ini masih bisa diatasi sebab sebelumnya guru menyampaikan bahwa akan memberikan reward bagi siswa yang mendapatkan nilai tertinggi dan tercepat dalam menyelesaikan soalsoal latihan.

Pertemuan kedua membahas mengenai gambar grafik fungsi linear dan menyelesaikan masalah yang berkaitan dengan grafik fungsi linear. Dengan menggunakan LKS siswa diingatkan kembali pada materi grafik fungsi linear yang sebenarnya telah diberikan pada jenjang sekolah menengah pertama, pada pertemuan kedua pembelajaran tidak terfokus dalam menggambar grafik fungsi linear lagi namun lebih menyelesaikan permasalahan-permasalahan grafik fungsi linear yang harus diselesaikan dengan cara kreatif

Pertemuan ketiga siswa mulai diajak dalam menyelesaikan suatu permasalahan yang berkaitan dengan fungsi kuadrat, siswa diberikan konsep awal tentang materi fungsi kuadrat pada pertemuan tersebut siswa diajukan suatu permasalahan yang harus perlu diselesaikan dengan pola berpikir kereatif, seperti mencari sumbu simetri dari persamaan kuadrat dalam beberapa cara, serta menentukan titik puncak suatu fungsi kuadrat dengan cara yang tidak lazim.

Pertemuan keempat siswa mulai diberikan konsep tentang menggambar grafik fungsi kuadrat meliputi cara, menentukan titik puncak dan sumbu simetri, kemudian siswa diberikan soal- 
soal dalam bentuk LKS yang diharapkan dapat merangsang kemampuan berpikir kreatif matematis siswa. Soal-soal yang diberikan meliputi, mencari nilai $\mathrm{k}$ pada persamaan parabola, dan membuat pemodelan fungsi kuadrat dari masalah sehari-hari.

\section{Penutup}

Kualitas peningkatan kemampuan berpikir kreatif matematis siswa yang mendapatkan Creative Problem Solving memperoleh interpretasi sedang. Hal itu menunjukan bahwa tidak terdapat peningkatan yang signifikan kemampuan berpikir kreatif matematis siswa yang menggunakan Creative Problem Solving.

Adapun saran dalam penelitian ini, Setelah model pembelajaran ini diterapkan dalam pembelajaran, akan lebih baik apabila peneliti selanjutnya memilih waktu belajar serta kelas yang memiliki kemampuan lebih dari kelas lainnya, hal itu mengingat kemampuan berpikir kreatif matematis merupakan suatu hal yang memerlukan keterampilan berpikir nalar tinggi.

\section{DAfTAR PUStaka}

Afriansyah, E. A. (2012). Design Research: Konsep Nilai Tempat pada Penjumlahan Bilangan Desimal. Tesis yang tidak dipublikasikan berasal dari Beasiswa DIKTI dengan program
IMPoME (International Master Program on Mathematics Education). Universitas Sriwijaya PalembangUniversitas UTRECHT Belanda.

Afriansyah, E. A. (2013). Penjumlahan Bilangan Desimal Melalui Permainan Roda Desimal. Prosiding Seminar Nasional Matematika dan Pendidikan Matematika, 233-240, Jurusan Pendidikan Matematika FMIPA UNY.

Afriansyah, E. A. (2014). What Students' Thinking about Contextual Problems is. Innovation and Technology for Mathematic, International Seminar on Innovation in Mathematics and Mathematics Education, 279-288, Departement of Mathematics Education Faculty of Mathematics and Natural Science Yogyakarta State University.

Afriansyah, E. A. (2015). Qualitative Became Easier with ATLAS.ti. International Seminar on Mathematics, Science, and Computer Science Education MSCEIS 2015 Universitas Pendidikan Indonesia.

Afriansyah, E. A. (2016). Enhancing Mathematical Problem Posing via Realistic Approach. International Seminar on Mathematics, Science, and Computer Science Education MSCEIS.

Afriansyah, E. A. (2017). Problem Posing sebagai Kemampuan Matematis. Mosharafa: Jurnal Pendidikan 
Matematika, 6(1), 163-180. DOI: https://doi.org/10.31980/moshar afa.v6i1.303

Afriansyah, E.A., Puspitasari, N., Luritawaty, I., Mardiani, D., \& Sundayana, R. (2019). The analysis of mathematics with ATLAS.ti. Journal of Physics: Conference Series 1402 (7), 077097.

BSNP. (2006). Peraturan Menteri Pendidikan Nasional Republik Indonesia Nomor 22 Tahun 2006 tentang Standar Isi untuk Satuan Pendidikan Dasar dan Menengah.

Damayanti, R., \& Afriansyah, E. A. (2018). Perbandingan Kemampuan Representasi Matematis Siswa antara Contextual Teaching and Learning dan Problem Based Learning. JIPM (Jurnal Ilmiah Pendidikan Matematika), 7(1), 30-39.

Dewi, S. S. S., \& Afriansyah, E. A. (2018). Kemampuan Komunikasi Matematis Siswa Melalui Pembelajaran CTL. JIPMat, 3(2).

Fatwa, V. C., Septian, A., \& Inayah, S. (2019). Kemampuan Literasi Matematis Siswa melalui Model Pembelajaran Problem Based Instruction. Mosharafa: Jurnal Pendidikan Matematika, 8(3), 389398.

DOI: https://doi.org/10.31980/moshar afa.v8i3.535

Gais, Z., \& Afriansyah, E. A. (2017). Analisis Kemampuan Siswa dalam Menyelesaikan Soal High Order
Thinking Ditinjau dari Kemampuan Awal Matematis Siswa. Mosharafa: Jurnal Pendidikan Matematika, 6(2), 255-266.

DOI: https://doi.org/10.31980/moshar afa.v6i2.313

Huda, M. (2011). Model-model Pengajaran dan Pembelajaran. Yogyakarta: Pustaka Pelajar.

Novi. (2016). Pengaruh Model Pembelajaran Missouri Mathematics terhadap Kemampuan Berpikir Kreatif Siswa. Jurnal Pendidikan Matematika Universitas Indraprasta PGRI Jakarta.

Lestari, T. P., \& Sofyan, D. (2013). Perbandingan Kemampuan Proses Pemecahan Masalah Antara Siswa Yang Menggunakan Pembelajaran Creative Problem Solving dan Konvensional. Mosharafa: Jurnal Pendidikan Matematika, 2(1), 179190.

Luritawaty, I. P. (2019). Pengembangan Kemampuan Komunikasi Matematik melalui Pembelajaran Take and Give. Mosharafa: Jurnal Pendidikan Matematika, 8(2), 239-248. DOI: https://doi.org/10.31980/moshar afa.v8i2.378

Maryanti, A. (2012). Hasil Pengembangan Lembar Kerja Siswa (LKS) Eksperimen dan Non-Eksperimen Berbasis Inquiri Terstruktur Pada Sub-pokok Materi Pergeseran Kesetimbangan Kimia. Tidak diterbitkan, Bandung.

Pangestu, N. S., \& Yunianta, T. N. H. (2019). Proses Berpikir Kreatif 
Matematis Siswa Extrovert dan Introvert SMP Kelas VIII Berdasarkan Tahapan Wallas. Mosharafa: Jurnal Pendidikan Matematika, 8(2), 215226.

DOI: https://doi.org/10.31980/moshar afa.v8i2.472

Pepkin, K. L. (2004). Creative Problem Solving in Math. http://www.uh.edu/hti/cu/2004/v02/ 04. Diakses pada tanggal 26 Juli 2018. Prayoga, S. (2013). Pengembangan Teknik Presentasi dan Diskusi pada pembelajaran. Journal Pendidikan, 2(3), 12-14.

Rahmi, I. (2015). Realistic Mathematics Education: Model Alternatif Pembelajaran Matematika Sekolah. JKPM IAIN, 1(2), 3-5.

Ridia, N. S., \& Afriansyah, E. A. (2019). Perbandingan

Kemampuan

Pemahaman Matematis Siswa melalui Auditory Intellectualy Repetition dan Student Teams Achievement Division. Mosharafa: Jurnal Pendidikan Matematika, 8(3), 515-526. DOI: https://doi.org/10.31980/moshar afa.v8i3.509

Setyanta, Y. B. (2013). Media Pembelajaran Berbasis Internet. EJournal Dinas Pendidikan Kota Surabaya, 1(2), 7.

Sumarmo, U. (2013). Berfikir dan Disposisi Matematik Serta Pembelajarannya.
Pada kumpulan makalah Jurusan Pendidikan Matematika UPI. Bandung: Tidak diterbitkan.

Tarlina, W. H., \& Afriansyah, E. A. (2016). Kemampuan Berpikir Kreatif Siswa Melalui Creative Problem Solving. EduMa: Mathematics Education Learning and Teaching, 5(2), 42-51. Retrieved

from http://journal.umpo.ac.id/index.php/s ilogisme/article/view/269/255

Teti, H. (2015). Peningkatan Kemampuan Berpikir Kritis dan Kreatif Siswa SMK serta Pengembangan Edukasi Diri Melalui Pengembangan Model Discovery Lerning. UPI Bandung.

\section{Riwayat Hidup PenUlis Ikhsan Faturrohman, S.Pd.}

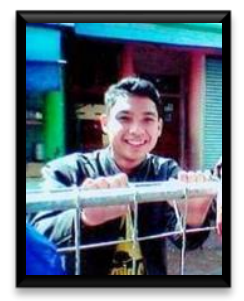

Lahir di Garut, 15 Oktober 1996. Staf pengajar di institusi mana. Studi S1 Pendidikan Matematika Institut Pendidikan Indonesia, Garut, lulus tahun 2019.

\section{Ekasatya Aldila Afriansyah, M.Sc.}

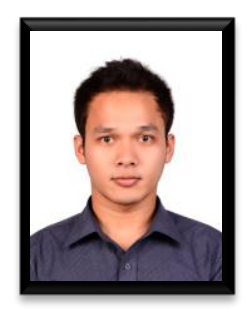

Lahir di Bandung, 4 April 1986. Dosen Tetap Yayasan STKIP Garut. Studi S1 Matematika Konsentrasi Statistika UPI, Bandung, lulus tahun 2009; S2 Pendidikan Matematika UNSRIUtrecht, lulus tahun 2012. 